\title{
Batas Minimal Usia Kawin Perspektif Hakim Pengadilan Agama dan Dosen Psikologi UIN Malang
}

\author{
Nizar Abdussalam \\ Fakultas Syariah UIN Maulana Malik Ibrahim Malang \\ abdussalam@yahoo.co.id
}

\begin{abstract}
:
This article aims to determine the minimum age to marry in the view of Malang District Court Judge Religion and the Faculty of Psychology UIN Maulana Malik Ibrahim Malang. Additionally, this article also aims to determine the relevance of the minimum limit of age at marriage that existed at Law No. 1 of 1974 on Marriage to apply today. This research is a field research using qualitative approach. The results of the discussion of this article shows that the Religious Court Judge Malang and Lecturer of Psychology UIN Malang agreed that the existing age limit in the Marriage Act is less suitable to be applied at this time. They would agree if the marriage age limit is raised. It aims to meet the maturity aspect of physical, psychological, and economic. So that domestic life is harmonious, eternal, and happy to be achieved.

Artikel ini bertujuan mengetahui batas minimal usia kawin menurut pandangan Hakim Pengadilan Agama Kabupaten Malang dan Dosen Fakultas Psikologi UIN Maulana Malik Ibrahim Malang. Selain itu, artikel ini juga bertujuan mengetahui relevansi batas minimal usia kawin yang ada pada Undang-Undang nomor 1 tahun 1974 tentang Perkawinan untuk diterapkan saat ini. Penelitian ini merupakan penelitian lapangan dengan menggunakan pendekatan kualitatif. Hasil pembahasan artikel ini menunjukkan bahwa Hakim Pengadilan Agama Kabupaten Malang dan Dosen Psikologi UIN Malang sepakat bahwa batasan usia yang ada pada UndangUndang Perkawinan kurang sesuai untuk diterapkan saat ini. Mereka lebih sepakat jika batasan usia perkawinan dinaikkan. Hal ini bertujuan untuk memenuhi aspek kematangan fisik, psikis, maupun ekonomi. Sehingga kehidupan rumah tangga yang harmonis, kekal, dan bahagia dapat tercapai.
\end{abstract}

Kata Kunci: usia kawin; psikologi; hakim

\section{Pendahuluan}

Perkawinan merupakan ketetapan Allah sebagai jalan untuk berkembang biak dan melestarikan keturunan bagi manusia. Dalam tatanan Islam kawin tidak hanya semata-mata untuk melestarikan keturunan, kawin akan menjadi ritual ibadah bila didahului dengan akad nikah yang sah. Dalam Kompilasi Hukum Islam (KHI) bab II pasal 2 dijelaskan bahwa pernikahan merupakan akad yang sangat kuat (mitsaqan ghalidhan) untuk mentaati perintah Allah dan melaksanakannya merupakan ibadah. ${ }^{1}$ Dalam pasal 1 Undang-undang nomor 1 tahun 1974, sebagai hukum positif perkawinan di Indonesia mendefenisikan perkawinan sebagai ikatan lahir batin antara seorang pria dan wanita sebagai suami-istri dengan tujuan membentuk

\footnotetext{
${ }^{1}$ Kompilasi Hukum Islam disebarluaskan melalui Instruksi Presiden Nomor 1 Tahun 1991 Jurisdictie: Jurnal Hukum dan Syariah Vol. 6 No. 2 Desember 2015
} 
keluarga yang bahagia dan kekal berdasarkan Ketuhanan Yang Maha Esa. ${ }^{2}$ Perkawinan bukan hanya ikatan perdata antara laki-laki dan perempuan. Banyak esensi-esensi yang lain yang terkandung dalam perkawinan. Selain sebagai sarana untuk legitimasi terhadap hubungan lakilaki dan perempuan perkawinan juga merupakan sarana untuk beribadah kepada Tuhan. Sebagaimana firman Allah SWT dalam Q.S. an-Nisa: 1 dan Q.S. Ar-Rum: 21. Dalam ajaran Islam, perkawinan merupakan sesuatu yang sakral, untuk itu ada ada aturan dan syarat tertentu.

Perkawinan bertujuan membentuk suatu keluarga yang merupakan elemen terkecil dalam kerangka sosial masyarakat. Keluarga yang harmonis akan mencetak dan membentuk bibit unggul bagi bangsanya. Keluarga harmonis dapat terbetuk jika pasangan telah matang dan siap untuk melakukan pernikahan. Kematangan emosi, fisik, pendidikan, dan ekonomi berpengaruh besar terhadap tingkat keharmonisan keluarga. Disamping itu faktor usia juga sangat berpengaruh, karena usia berbanding lurus dengan kematangan psikologi dan emosi. Semakin dini usia calon pengantin semakin rendah pula kematangan psikologi dan kontrol emosinya, sehingga dapat mengakibatkan disfungsi keluarga yang berujung pada keretakan rumah tangga. Bagi seorang pemuda, untuk memasuki gerbang perkawinan dan kehidupan berumah tangga pada umumnya dititikberatkan pada kematangan jasmani dan kedewasaan pikiran orang serta kesanggupannya untuk memikul tanggung jawab sebagai suami dalam rumah tangganya. Hal itu merupakan patokan kematangan umur bagi para pemuda kecuali ada faktor lain yang menyebabkan harus dilaksanakannya pernikahan lebih cepat. ${ }^{3}$ Bagi sorang gadis usia perkawinan itu berkaitan dengan kematangan fisik dan kehamilan. Disamping itu kematangan rohani juga dianggap penting, yang memungkinkan ia dapat menjalankan tugas sebagai seorang istri dan sekaligus sebagai seorang ibu yang sebaik-baiknya.

Jika diambil patokan yang paling bagus bagi seorang gadis untuk menjalankan perkawinan yang sesuai dengan keadaan di Indonesia batas terendah bagi bagi seorang gadis adalah 18 tahun, karena pada umur 18 seorang wanita sudah mencapai tingkat kematangan biologis seorang wanita. ${ }^{4}$ Islam tidak memberikan batasan minimal usia kawin secara gamblang. Batasan usia kawin hanya didasarkan pada standar usia baligh saja. Beberapa ulama' mengemukakan pendapatnya mengenai usia baligh. Menurut Imam Abu Hanifah dapat dikatakan baligh bagi seorang laki-laki apabila telah ihtilam yaitu bermimpi nikmat sehingga keluar mani dan bagi seorang wanita jika sudah mengeluarkan darah haid. Pendapat Abu Hanifah ini sangat relevan dengan zaman saat ini karena usia belum tentu dapat menentukan kapan seseorang mengalami ihtilam (mimpi basah) bagi seorang laki-laki dan belum tentu keluar haid bagi seorang perempuan. Terkadang umur 12 sudah mengalami mimpi basah bagi laki-laki dan umur 9 tahun seorang perempuan sudah mengeluarkan darah haid. Hukum Islam memberi ketentuan bahwa kedewasaan laki-laki ditandai dengan keluar mani dan perempuan dengan keluarnya darah haid. ${ }^{5}$

Dalam undang-undang nomor 1 tahun 1974 tentang perkawinan pasal 7 ayat (1) dinyatakan bahwa: "Perkawinan hanya diizinkan bila pihak pria mencapai umur 19 (sembilan belas) tahun dan pihak wanita sudah mencapai usia 16 (enam belas) tahun." Limitasi minimum usia kawin pada undang-undang perkawinan ini merupakan unifikasi usia kawin dari beberapa sumber dan literatur sebagai acuan tetap hakim untuk memutus perkara kawin. Karena

\footnotetext{
${ }^{2}$ Undang-undang Nomor 1 Tahun 1974 Tentang Perkawinan Lembar Negara Tahun 1974 Nomor 1

3 Sutan Marajo Nasaruddin Latif, Problematika Seputar Keluarga Dan Rumah Tangga (Bandung: Pustaka Hidayah, 2001), 23.

${ }^{4}$ Latif, Problematika Seputar Keluarga Dan Rumah Tangga, 23.

${ }^{5}$ Wahbah Az-Zuhaili, Al-Fiqh Al-Islam Wa Adillatuhu, (Beirut: Dar al-Fikr, 2008), 423-424.

Jurisdictie: Jurnal Hukum dan Syariah Vol. 6 No. 2 Desember 2015
} 
sebelum terbentuknya undang-undang ini hakim merujuk pada kitab-kitab turats yang sangat varian dalam memberikan limitasi minimum usia kawin. Angka 19 tahun bagi laki-laki dan 16 tahun bagi perempuan ini juga berdasar pada kultur dan kondisi masyarakat Indonesia. Angka ini dianggap sesuai dengan masyarakat Indonesia. Yusuf Hanafi menyatakan bahwa India merupakan negara dengan jumlah kekerasan dalam rumah tangga (KDRT) tertinggi. Hal ini disebabkan banyaknya wanita mereka yang menikah di usia muda / di bawah batas usia layak nikah. $^{6}$

Data statistik yang diperoleh dari situs resmi Pengadilan Agama Kabupaten Malang menyatakan bahwa Jumlah perkara yang diterima di Pengadilan Agama Kabupaten Malang adalah 5736 kasus. 1677 berupa kasus cerai talak, 3219 berupa kasus cerai gugat, dan sisanya adalah kasus lain. Hampir 80\% kasus yang ada di Pengadilan Agama Kabupaten Malang adalah kasus cerai. ${ }^{7}$ Disinyalir terdapat korelasi antara angka perceraian tersebut dengan limitasi minimum usia kawin pada undang-undang perkawinan yang relatif rendah. Angka tersebut dianggap terlalu rendah, karena pada usia ini seseorang hanya matang dalam segi fisik saja. Belum dapat dikatakan matang secara psikis, ekonomi, dan emosi. Lubab, Dosen Fakultas Pikologi UIN Malang menyatakan bahwa kematangan biologis dan psikis berbanding terbalik.

Saat ini kematangan biologis seseorang relatif lebih cepat, sebaliknya kematangan psikis seseorang (termasuk didalamnya aspek emosi, tanggung jawab, dan ekonomi) justru semakin lambat, hal ini disebabkan oleh kultur yang ada di masyarakat saat ini. M. Nur Syafiuddin, Hakim Pengadilan Agama Kabupaten Malang menyatakan bahwa dari 10 kasus permohonan dispensasi kawin 8 diantaranya kembali lagi ke Pengadilan Agama untuk mengajukan cerai. Hal ini menunjukkan bahwa kesiapan calon pengantin sangat dibutuhkan dalam perkawinan. berdasarkan berbagai persoalan di atas, diketahui bahwa batas minimal usia kawin yang ada pada Undang-undang Perkawinan nampaknya tidak dapat mengakomodir kebutuhan masyarakat saat ini. Untuk itu, artikel ini bertujuan mengetahui batas minimal usia kawin menurut pandangan Hakim Pengadilan Agama Kabupaten Malang dan Dosen Fakultas Psikologi UIN Maulana Malik Ibrahim Malang. Selain itu, artikel ini juga bertujuan mengetahui relevansi batas minimal usia kawin yang ada pada Undang-Undang nomor 1 tahun 1974 tentang Perkawinan untuk diterapkan saat ini.

\section{Metode Penelitian}

Penelitian ini termasuk jenis penelitian lapangan (field research). Karena berupaya menggali data dengan melakukan wawancara terhadap Hakim Pengadilan Agama Kabupaten Malang dan Dosen Psikologi UIN Malang mengenai pandangan mereka terhadap batas minimal usia kawin yang ada pada Undang-undang Perkawinan Nomor 1 Tahun 1974. Pendekatan yang digunakan dalam penelitian ini adalah pendekatan kualitatif. ${ }^{8}$ Data primer dari penelitian ini adalah hasil wawancara kepada Hakim Pengadilan Agama Kabupaten Malang dan Dosen Psikologi UIN Malang. Wawancara dilakukan terhadap beberapa Hakim di Pengadilan Agama Kabupaten Malang, yaitu: M. Nur Syafiuddin, Nurul Maulidia. Wawancara juga dilakukan terhadap beberapa dosen Psikologi UIN Malang, yaitu: Fathul Lubabin Nuqul, Elok Halimatus Sakdiyah.

\footnotetext{
${ }^{6}$ Yusuf Hanafi, Kontroversi Perkawinan Anak Di Bawah Umur Perspektif Fikih Islam, HAM Internasional, Dan UU Nasional (Bandung: Mandar Maju, 2011), 89.

7 “Jenis Perkara yang diterima di Pengadilan Agama Kabupaten Malang tahun 2014", http://www.pamalangkab.go.id/index.php/sjp2, diakses 2 Januari 2015

${ }^{8}$ Suharsimi Arikunto, Prosedur Penelitian: Suatu Pendekatan Praktek (Jakarta: Rineka Cipta, 2006), 246.
}

Jurisdictie: Jurnal Hukum dan Syariah Vol. 6 No. 2 Desember 2015 


\section{Hasil dan Pembahasan \\ Pandangan Hakim Pengadilan Agama Kabupaten Malang Mengenai Batas Minimal Usia Kawin}

Sebagaimana dijelaskan dalam pasal 7 ayat (1) Undang-Undang Nomor 1 Tahun 1974 tentang Perkawinan bahwa limitasi minimal usia kawin bagi lelaki adalah 19 tahun, sedangkan bagi perempuan 16 tahun.64 Dalam penjelasan pasal 7 ayat (1) Undang-Undang Nomor 1 Tahun 1974 dinyatakan bahwa untuk menjaga kesehatan suami-istri dan keturunan, perlu ditetapkan batas-batas umur untuk perkawinan.65 Berbicara mengenai substansi hukum dalam Undang-Undang Perkawinan, dapat dinyatakan bahwa dalam kontennya terdapat inkonsistensi substansi pasal-pasal yang ada. Di satu sisi terdapat pasal yang memberikan limitasi minimum terhadap pasangan yang ingin menikah yang dijelaskan dalam Pasal 7 ayat (1). Namun di sisi lain dalam Pasal 7 Ayat (2) dijelaskan bahwa pasangan yang belum mencapai usia tersebut dapat mengajukan dispensasi kawin ke Pengadilan Agama yang dimintakan oleh kedua orang tua pihak pria atau wanita. Kemudian tidak ada aturan yang jelas dalam Undang-Undang Perkawinan yang mengatur tentang kriteria dasar diperbolehkannya seseorang menikah dibawah batas usia kawin, yang kemudian hal ini dalam praktiknya dibebankan kepada para hakim, selaku pelaksana hukum yang memeriksa dan memutus kasus ini. ${ }^{9}$

Dalam tataran praktis kasus perceraian selalu membeludak dibanding dengan kasus-kasus yang lain. Sebagai contoh data statistik yang ada di Pengadilan Agama Kabupaten Malang, dari 5736 kasus, 4896 diantaranya adalah kasus cerai, baik itu cerai gugat maupun cerai talak. Disinyalir bahwa salah satu penyebab banyaknya kasus perceraian tersebut adalah ketidaksiapan pasangan dalam membangun rumah tangga.

Ketidaksiapan ini disebabkan oleh usia pasangan saat menikah relatif rendah. Rendahnya usia pasangan saat menikah berimbas pada ketidakharmonisan keluarga, bahkan bisa berujung pada perceraian. Hal ini dikuatkan dengan fakta bahwa sebagian besar dari pihak yang mengajukan dispensasi kawin ke Pengadilan Agama Kabupaten Malang, mereka kembali lagi ke Pengadilan Agama beberapa bulan kemudian untuk mendaftarkan kasus perceraian, baik itu cerai gugat maupun cerai talak. Fenomena di atas menunjukkan bahwa kedewasaan seseorang, baik secara fisik maupun psikis sangatlah penting dalam membangun bahtera rumah tangga. Kedewasaan ini bisa digeneralisir dengan patokan usia. Sebagian besar dari pihak yang mengajukan dispensasi kawin ke Pengadilan Agama mereka sudah dalam keadaan hamil. Jika diprosentasekan 90\% dari pihak-pihak yang mengajukan dispensasi kawin sudah dalam keadaan hamil. ${ }^{10}$ Hakim sebagai pemutus perkara tersebut selalu mempertimbangkan unsur kemanfaatan dan kemudharatan. Melihat dari sudut pandang anak yang masih ada dalam kandungan, jika ia lahir tanpa memiliki hubungan keperdataan dengan seorang bapak, maka masa depan anak tersebut menjadi dipertanyakan. Sehingga sebagian besar kasus-kasus dispensasi kawin tersebut dikabulkan oleh majlis hakim. Sejalan dengan hal itu, berdasarkan data hasil wawancara dapat dinyatakan bahwa banyak diantara pasangan yang menikah pada saat usia mereka dibawah 21 tahun mengalami kegagalan dalam membangun rumah tangga. Mereka mengajukan permohonan cerai ke Pengadilan Agama, baik itu cerai gugat maupun cerai talak dengan alasan yang sangat bervarian, seperti sering bertengkar, perselingkuhan, tidak tanggungjawab, dan lain sebagainya.

\footnotetext{
${ }_{9}$ Amir Syarifuddin, Hukum Perkawinan Islam di Indonesia: Antara Fiqh Munakahat dan Undang-Undang Perkawinan (Jakarta: Kencana, 2008), 35.

${ }^{10}$ Nurul Maulidiah, Wawancara, (Pengadilan Agama Kab. Malang, 3 Maret 2015).

Jurisdictie: Jurnal Hukum dan Syariah Vol. 6 No. 2 Desember 2015
} 
Berbagai faktor penyebab perceraian di atas merupakan implikasi dari ketidaksiapan mereka untuk menjalani kehidupan rumah tangga, terutama kesiapan dari segi psikis. ${ }^{11}$ Ditinjau dari sisi historis, perumusan Undang-Undang Perkawinan merupakan jawaban pemerintah dari beberapa tuntutan mengenai unifikasi aturan mengenai perkawinan. Dalam penjelasan pasal 7 ayat (1) UndangUndang Nomor 1 Tahun 1974 dinyatakan bahwa untuk menjaga kesehatan suami-istri dan keturunan, perlu ditetapkan batas-batas umur untuk perkawinan. ${ }^{12}$ Alasan mengapa memilih angka 19 dan 16 tersebut, tidak ada referensi yang menjelaskan secara rinci mengenai hal ini. Secara tidak langsung mungkin dapat dikatakan bahwa Undang-Undang Perkawinan merupukan suatu bentuk pemenuhan "kebutuhan " pihak-pihak yang turut andil dalam perumusan undang-undang tersebut. Sehingga tidak seluruh pasal yang ada dapat mengakomodir kepentingan masyarakat. Pencantuman limitasi usia minimal kawin pada Undang-Undang Perkawinan bertujuan untuk melindungi masyarakat dari beberapa dampak yang timbul dari perkawinan di usia muda. Baik itu dampak kesehatan maupun dampak terhadap keharmonisan keluarga. Dari sisi kesehatan,pernikahan di usia dini berdampak negatif pada kesehatan organ reproduksi, terutama bagi wanita. Namun lebih dari itu lebing penting lagi adalah kondisi keharmonisan keluarga yang benar-benar harus dijaga, hal ini bisa diantisipasi dengan menghindari pernikahan di usia muda.

Dari hasil wawancara dengan beberapa Hakim di Pengadilan Agama Kabupaten Malang, sebagian besar dari mereka kurang sepakat dengan batasan minimal usia kawin yang ada pada Undang-Undang Perkawinan. Karena fakta yang ada batasan usia minimal tersebut kurang bisa mengakomodir kepentingan rakyat. Dari paparan diatas peneliti dapat menarik sebuah konklusi bahwa batasan minimal usia kawin pada Undang-Undang Perkawinan patut dipertanyakan eksistensinya. Apakah batasan tersebut masih layak diterapkan pada masyarakat kita, atau justru sebaliknya. Nampaknya batasan minimal usia kawin tersebut perlu untuk direkonstruksi. Jika muncul dua pilihan, apakah batasan umur tersebut dinaikkan atau justru malah diturunkan. Maka peneliti menjawab bahwa seyogyanya batasan umur tersebut dinaikkan, setidaknya 21 bagi laki dan 18 bagi perempuan. Pernyataan tersebut berdasar pada beberapa fakta yang ada di lapangan. Bahwa, banyak dari mereka yang menikah di bawah usia 21 tahun yang mengalami kegagalan dalam membangun rumah tangga. Di samping itu pemilihan usia ini juga merupakan suatu upaya agar tidak terjadi ketimpangan antara peraturan perundang-undangan. Karena dalam Undang-Undang Perlindungan Anak dijelaskan bahwa anak adalah mereka yang berada pada usia 18 tahun kebawah, dan mereka tidak boleh di eksploitasi haknya, termasuk dari bentuk eksploitasi adalah menikahkan mereka di usia dini. Pemilihan usia 21 tahun bagi lakilaki ini merujuk pada Kitab UndangUndang Hukum Perdata (KUHPer), dalam KUHPer dijelaskan bahwa seseorang bisa dikatakan dewasa ketika menginjak usia 21 tahun. Apabila muncul statemen bahwa jika batas usia kawin tersebut diturunkan maka hal ini dapat meminimalisir dispensasi kawin, maka peneliti sepakat akan hal itu. Namun yang menjadi target utama adalah meminimalisir perceraian dan disharmoni keluarga, bukan meminimalisir dispensasi kawin.

Jika batas usia kawin di naikkan, maka hal ini dapat mewujudkan cita-cita luhur perkawinan yang ada dalam KHI, yaitu membentuk keluarga yang sakinah, mawaddah, dan rahmah. Karena dengan menaikkan usia kawin, maka pengantin akan lebih matang dalam membina rumah tangga. Lebih jauh lagi, permohonan kasus dispensasi kawin yang ada di

\footnotetext{
${ }^{11}$ Nurul Maulidiah, Wawancara, (Pengadilan Agama Kab. Malang, 3 Maret 2015).

12 Muhammad Amin Suma, Himpunan Undang-Undang Perdata Islam \& Peraturan Pelaksanaan Lainnya di Negara Hukum Indonesia (Jakarta: RajaGrafindo Persada, 2004), 348.
}

Jurisdictie: Jurnal Hukum dan Syariah Vol. 6 No. 2 Desember 2015 
lapangan bukan karena murni mereka ingin menikah di usia tersebut, namun $90 \%$ dari pemohon adalah mereka yang telah hamil di luar nikah / MBA (married by accident). Agar usulan ini dapat terlaksana dengan baik, perlu dibarengi dengan adanya penambahan pasal-pasal pada sub dispensasi kawin yang menjelaskan mengenai syarat-syarat permohonan dispensasi kawin. Hal ini dimaksudkan agar hakim lebih mudah dalam memeriksa dan memutus perkara dispensasi kawin ini. Perlu diusulkan juga agar syarat-syarat pengajuan dispensasi kawin ini diperketat, supaya kasus dispensasi kawin ini dapat diminimalisir. Sejalan dengan itu, untuk membentuk masyarakat yang pro-aktif terhadap ketentuan batasan usia kawin ini perlu dilakukas sosialisasi secara intens, terutama di daerah-daerah plosok desa. Mungkin hal ini menjadi tanggung jawab bersama Pengadilan Agama, Kantor Urusan Agama, dan Perangkat Desa. Dengan demikian akan tercipta masyarakat yang sehat, sejahtera, bahagia, dan aman dari perceraian.

\section{Pandangan Dosen Psikologi UIN Malang Mengenai Batas Minimal Usia Kawin}

Berbicara mengenai usia dan kedewasaan, nampaknya psikologi merupakan bidang ilmu yang sesuai untuk membahas hal ini. Dalam keilmuan ini terdapat bahasan mengenai tahaptahap perkembangan individu, baik secara fisik maupun secara psikis, namun yang lebih banyak di bahas dan menjadi perdebatan adalah perkembangan individu dari sisi psikisnya. Berdasarkan fakta yang ada di lapangan, saat ini remaja lebih cepat dewasa secara biologis dari pada remaja pada zaman dahulu. Hal ini disebabkan oleh beberapa faktor, seperti perhatian orang tua, pendidikan, dan lingkungan sosial yang ada. Kondisi orang tua saat ini yang cenderung lepas kontrol terhadap anak-anaknya, ditambah dengan lingkungan yang sangat tidak mendukung bagi pembentukan moral anak menjadikan seorang anak terutama yang telah menginjak remaja lebih cepat dewasa secara biologis. Kasus ini banyak terjadi pada ibu-ibu dari remaja yang menjadi wanita karir, karena tidak ada yang menggantikan posisinya di rumah sebagai pengasuh dan pendidik anak, maka hal ini menjadikan anaknya terjun dalam lingkungan dan pergaulan yang sangat tidak mendukung.

Kedewasaan remaja secara psikis justru malah mengalami kemunduran. Hal ini disebabkan beberapa faktor, kemajuan teknologi tidak dibarengi dengan perkembangan moral di kalangan remaja saat ini. Kondisi ini mengakibatkan mereka menjadi bersifat kekanakkanakan, dan cenderung menonjolkan ego, serta hanya memperhatikan kepentingannya sendiri. Namun sebaliknya dari sisi biologis mereka justru lebih cepat matang. ${ }^{13}$ Hal ini sejalan dengan pernyataan yang diutarakan oleh Elok Halimatus Sakdiyah, Dosen Psikologi UIN Malang. Beliau menyatakan bahwa setiap satu dasawarsa seorang individu mengalami kemajuan kematangan biologis sebanyak empat bulan, namun hal ini tidak dibarengi dengan kematangan psikisnya. ${ }^{14}$ Berbicara mengenai kematangan, menurut Wasti Sumanto seorang individu mengalami kematangan secara fisik dalam kisaran usia 17-20 tahun. ${ }^{15}$ Dalam literatur yang berbeda Zulkifli menyatakan bahwa seorang gadis perkembangan biologisnya lebih cepat satu tahun dibandingkan dengan perkembangan biologis seorang pemuda, karena gadis lebih dahulu mengawali remaja yang akan berakhir pada sekitar usia 19 tahun, sedangkan pemuda baru mengakhiri masa remajanya pada sekitar usia 21 tahun. ${ }^{16}$

\footnotetext{
${ }^{13}$ Lubab, Wawancara, (Fakultas Psikologi UIN Malang, 12 Maret 2015).

${ }^{14}$ Elok, Wawancara, (Fakultas Psikologi UIN Malang, 20 Maret 2015).

${ }^{15}$ Wasty Soemanto, Psikologi Pendidikan Landasan Kerja Pemimpin Pendidikan (Jakarta: Rineka Cipta, 1984), 67.

${ }^{16}$ Zulkifli, Psikologi Perkembangan (Bandung: PT Remaja Rosdakarya, 2005), 64.

Jurisdictie: Jurnal Hukum dan Syariah Vol. 6 No. 2 Desember 2015
} 
Kemudian menurut J.J. Roesseau kematangan individu secara psikis akan tercapai pada saat mereka berumur 20 tahun. ${ }^{17}$ Sejalan dengan J.J. Roesseau, Sullivan mengemukakan bahwa manusia yang berumur lebih dari 20 tahun memasuki periode maturity (kematangan). ${ }^{18}$ Kemudian, Kohnstamm dalam bukunya Pribadi dalam Perkembangan (Persoonlijkheid in wording) menyatakan bahwa masa dewasa (matang) adalah masa dimana seseorang berada pada usia 21 tahun ke atas. ${ }^{19}$ Erik Erikson, seorang ahli psikologi perkembangan menyatakan bahwa kematangan individu dicapai saat mereka menginjak usia 20 tahun. Dalam tahap ini, perkembangan fungsi kehendak mulai dominan. Orang mulai dapat membedakan adanya tiga macam tujuan hidup pribadi, yaitu pemuasan keinginan pribadi, pemuasan keinginan kelompok, dan pemuasan keinginan masyarakat. Semua ini direalisasikan oleh individu dengan belajar mengendalikan kehendaknya. Dengan kemauannya, orang melatih diri untuk memilih keinginan-keinginan yang akan direalisasikan dalam bentuk tindakan-tindakannya. Realisasi setiap keinginan ini menggunakan fungsi penalaran, sehingga orang dalam masa perkembangan ini mulai mampu melakukan self direction dan self controll.

Dengan kemampuan keduanya ini, maka manusia tumbuh dan berkembang menuju kematangan untuk hidup berdiri sendiri dan bertanggung jawab. ${ }^{20}$ Dari paparan diatas dapat disimpulkan bahwa kedewasaan seseorang akan dicapai pada usia sekitar 20 tahun. Hal ini menunjukkan bahwa batasan minimal usia kawin yang ada pada Undang-Undang Perkawinan bersebrangan dengan batas kematangan dan kedewasaan seseorang dalam perpspektif psikologi. Diperkuat lagi bahwa rentan waktu antara 1974 hingga saat ini cukuplah lama. Sangat memungkinkan terjadi pergeseran konsep kematangan dan kedewasaan pada diri manusia saat ini. Karena kematangan dan kedewasaan sangat bergantung pada kondisi lingkungan dan kultur yang ada. Dan seperti yang kita ketahui bahwa lingkungan dan kultur saat ini sangatlah berbeda dengan zaman dahulu. Berdasar pada hal-hal di atas, nampaknya batas minimal usia kawin yang ada pada Undang-Undang Perkawinan perlu direvisi. Sebagai acuan standar kedewasaan untuk melakukan perkawinan, 21 tahun bagi lelaki dan 18 tahun bagi perempuan dirasa patut menjadi revisi dari angka sebelumnya, yaitu 19 tahun bagi laki-laki dan 16 tahun bagi perempuan.

Dengan asumsi bahwa di usia 18 tahun seorang wanita telah melewati jenjang pendidikan SMAnya, dalam kondisi ini seorang wanita telah patut untuk melangsungkan pernikahan. Pendidikan SMA dirasa cukup sebagai bekal seorang wanita untuk melangkah ke jenjang perkawinan. Berbeda dengan wanita, kesiapan seorang lelaki untuk melakukan pernikahan tidak hanya masalah pendidikan (tamat SMA), seorang lelaki juga harus memiliki kematangan ekonomi yang dapat diindikasikan dari pekerjaan yang ia miliki (pekerjaan apapun). Dan pada usia 21 tahun ini seorang laki-laki berusaha memantapkan tujuan vokasional dan mengembangkan sense of personal identy. Keinginan yang kuat untuk menjadi matang dan diterima dalam kelompok teman sebaya dan orang dewasa. ${ }^{21}$ Seorang lelaki harus melalui tahap ini, karena ia akan menjadi kepala keluarga yang menjadi penanggungjawab atas rumah tangga yang ia bangun.

\footnotetext{
${ }^{17}$ Soemanto, Psikologi Pendidikan Landasan Kerja Pemimpin Pendidikan, 69.

${ }^{18}$ Alwisol, Psikologi Kepribadian (Malang: UMM Press, 2007), 160.

${ }^{19}$ Zulkifli, Psikologi Perkembangan, 20.

${ }^{20}$ Soemanto, Psikologi Pendidikan Landasan Kerja Pemimpin Pendidikan, 69.

${ }^{21}$ Hendriati Agustiani, Psikologi Perkembangan: Pendekatan Ekologi Kaitannya Dengan Konsep Diri Dan Penyesuaian Diri Pada Remaja (Bandung: Refika Aditama, 2006), 29.
}

Jurisdictie: Jurnal Hukum dan Syariah Vol. 6 No. 2 Desember 2015 


\section{Relevansi Batas Minimal Usia Kawin Pada UU No. 1 Tahun 1974}

Dibentuknya sebuah peraturan perundang-undangan bertujuan untuk mengatur masyarakat agar tercipta masyarakat yang tertib dan nyaman. Dirumuskannya Undang-Undang No. 1 Tahun 1974 Tentang Perkawinan merupakan sebuah jawaban dari reaksi yang ditimbulkan oleh berbagai kalangan masyarakat. Banyak diantara mereka yang menuntut adanya perumusan Undang-Undang Perkawinan secara keseluruhan. Karena pada periode sebelumnya dasar hukum mengenai perkawinan dan turunannya tidak terkodifikasi secara sempurna. Undang-undang dan masyarakat semestinya berjalan secara beriringan. Dengan demikian akan tercipta ketertiban dan kenyamanan. Hal ini belum terwujud dalam pelaksanaan Undang-Undang Perkawinan. Salah satu misi dari Undang-Undang Perkawinan adalah menekan fenomena pernikahan dini. Terbukti, pasal 7 ayat (1) undang-undang ini memberikan batasan minimal usia kawin bagi pasangan yang ingin menikah, yakni 19 tahun bagi laki-laki dan 16 tahun bagi perempuan. ${ }^{22}$ Namun kenyataan yang ada masih banyak masyarakat yang melakukan perkawinan di bawah umur. Banyak dari mereka yang mengajukan permohonan dispensasi kawin ke Pengadilan Agama agar dapat melangsungkan perkawinan meskipun mereka belum memenuhi kriteria usia minimal kawin. ${ }^{23}$ Banyaknya fenomena pernikahan dini secara tidak langsung memang didukung oleh substansi pasal dari Undang-Undang Perkawinan itu sendiri.

Adanya kontradiksi antara pasal 7 ayat (1) tentang batasan minimal usia kawin dan pasal 7 ayat (2) tentang kebolehan mengajukan permohonan dispensasi kawin, serta tidak adanya persyaratan yang jelas dan ketat pada pasal ini menjadi peluang bagi masyarakat yang ingin menikah di usia dini. ${ }^{24}$ Setidaknya ada empat alasan terjadinya kontradiksi dalam pasal 7 Undang-Undang Perkawinan, yaitu: Pertama, pembuat RUU Perkawinan mengadopsi rumusan pembatasan usia perkawinan dan ketentuan dispensasi dalam Burgerlijk Wetboek tanpa memberikan alasan pendukung yang lengkap. Kedua, pemerintah ingin melindungi hak asasi warga negara dalam perkawinan. Sajuti Melik menyatkan bahwa Undang-Undang Perkawinan digunakan untuk seluruh warga negara. Jangan dengan adanya undang-undang perkawinan kemudian sebagian warga negara tidak bisa kawin karena tidak memenuhi persyaratan. Batas usia yang terlalu tinggi daripada usia dewasa dikhawatirkan menimbulkan dampak negatif terhadap generasi muda karena terhambat peraturan perundang-undangan. Ketiga, pemerintah menyadari kekuatan sosial-politik umat Islam pada saat perumusan Undang-Undang Perkawinan. Sebagai kelompok mayoritas, umat Islam di Indonesia mampu dengan mudah dimobilisasi oleh isu-isu keagamaan, khususnya berkaitan dengan upaya kristenisasi atau gerakan anti pelembagaan hukum Islam. Sebagai bukti, pembahasan RUU Perkawinan pada tahun 1973 nyaris setiap hari diwarnai demonstrasi baik di Jakarta maupun di berbagai wilayah lainnya. Dalam persoalan politik praktis saat itu, umat Islam juga memiliki posisi yang kuat. Sehingga perundingan-perundingan di luar persidangan DPR mampu mempengaruhi pembahasan RUU Perkawinan selanjutnya. Agar tidak terjadi gejolak sosial atas diberlakukannya batas usia perkawinan, pemerintah nampaknya memberikan jalan keluar berupa dispensasi perkawinan. Keempat, pemerintah tidak mau "ambil pusing" dengan urusan privat warga negara. Selama persoalan tersebut tidak berkaitan erat dengan stabilitas politik

\footnotetext{
${ }^{22}$ Syarifuddin, Hukum Perkawinan Islam di Indonesia, 29.

${ }^{23}$ Nurul Maulidiah, wawancara, (Pengadilan Agama Kab. Malang, 3 Maret 2015).

${ }^{24}$ Syafiuddin, wawancara, (Pengadilan Agama Kab. Malang, 4 Maret 2015).

Jurisdictie: Jurnal Hukum dan Syariah Vol. 6 No. 2 Desember 2015
} 
nasional atau kedudukan status quo saat itu, pemerintah menyerahkan segala penyelesaian perkara pada masyarakat, termasuk dalam bidang perkawinan. ${ }^{25}$

Melalui pasal 7 ayat (1) tersebut, Undang-Undang Perkawinan juga bertujuan untuk meminimalisir adanya keretakan rumah tangga dan perceraian. Namun keinginan luhur pasal ini sangat kontradiktif dengan fakta yang ada di Pengadilan Agama Kabupaten Malang. Dari data statistik yang ada di Pengadilan Agama Kabupaten Malang, dari 5736 kasus, 4896 diantaranya adalah kasus cerai, baik itu cerai gugat maupun cerai talak. Secara teoritis, Lawrence M. Friedman mengemukakan ada tiga unsur yang harus diperhatikan dalam penegakan hukum. Ketiga unsur tersebut adalah struktur, substansi, dan budaya hukum. ${ }^{26}$ Soerjono Soekanto mengemukakan lima faktor yang sangat berpengaruh pada penegakan hukum, yaitu: faktor hukum atau undangundang, faktor penegak hukum, faktor sarana atau fasilitas, faktor masyarakat, dan faktor kebudayaan. ${ }^{27}$ Pada dasarnya apa yang dikehendaki oleh Soerjono Soekanto sama dengan apa yang dikemukakan Lawrence M. Friedman, yaitu unsur struktur hukum, substansi hukum, dan budaya hukum. Berkaitan dengan Undang-Undang Perkawinan nampaknya substansi hukum yang ada didalamnya patut dipertanyakan. Dalam penelitian ini yang menjadi konsentrasi bahasan adalah mengenai batasan minimal usia kawin yang tertera pada pasal 7 ayat (1) Undang-Undang Perkawinan. Pasal ini dianggap tidak dapat mengakomodir masyarakat. Terbukti masih banyak kasus perceraian yang ada di masyarakat. Berdasarkan hasil wawancara didapati bahwa diantara faktor penyebab perceraian tersebut adalah ketidaksiapan mereka dari sisi usia. Banyak remaja yang menikah dibawah usia 21 tahun yang mengalami kegagalan dalam membina rumah tangga. ${ }^{28}$ Hal ini diperparah dengan budaya hukum yang ada pada masyarakat saat ini.

Pernikahan dan perceraian sudah tidak menjadi hal yang penting dalam keseharian mereka. Dapat diistilahkan bahwa saat ini terjadi desakralisasi pernikahan dan perceraian, keduanya dianggap sebagai hal yang biasa-biasa saja. Sehingga masyarakat kita cenderung acuh terhadap aturanaturan tentang perkawinan dan perceraian. Banyak juga dari mereka yang melakukan perkawinan di usia muda, bahkan sebagian masyarakat ada yang beranggapan bahwa kawin di usia muda merupakan suatu kebanggaan tersendiri. ${ }^{29}$ Ketika kita kembalikan kepada paparan Lawrence dan Soerjono, maka didapati bahwa dua dari tiga unsur yang dibutuhkan dalam penegakan undang-undang belum terpenuhi secara maksimal, yaitu unsur substansi dan budaya hukum. Hal ini mengakibatkan pemberlakuan undang-undang perkawinan tidak berjalan efektif. Untuk dapat mengetahui efektifitas hukum maka pertama kali yang harus dilihat adalah, sejauh mana aturan hukum itu ditaati atau tidak ditaati. Tentu saja, jika suatu aturan hukum ditaati oleh sebagian besar target yang menjadi sasaran ketaatannya, kita akan mengatakan bahwa aturan hukum yang bersangkutan adalah efektif. Namun demikian, sekalipun dapat dikatakan aturan yang ditaati itu efektif, tetapi kita masih dapat mempertanyakan lebih jauh derajat efektifitasnya. ${ }^{30}$ Berdasarkan prinsip pasif-dinamis (hukum atau undang-undang berbunyi demikian karena kondisi masyarakat seperti demikian). ${ }^{31}$

\footnotetext{
${ }^{25}$ Ramadhita, "Diskresi Hakim: Pola Penyelesaian Kasus Dispensasi Perkawinan," De Jure: Jurnal Hukum Dan Syar'iah 6, no. 1 (June 30, 2014): 67, doi:10.18860/j-fsh.v6i1.3192.

${ }^{26}$ Salim HS and Erlies Septiana Nurbani, Penerapan Teori Hukum Pada Penelitian Tesis Dan Disertasi (Jakarta: PT RajaGrafindo Persada, 2013), 305.

${ }^{27} \mathrm{HS}$ and Nurbani, Penerapan Teori Hukum, 307.

${ }^{28}$ Nurul Maulidiah, wawancara, (Pengadilan Agama Kab. Malang, 3 Maret 2015).

${ }^{29}$ Lubab, Wawancara, (Fakultas Psikologi UIN Malang, 12 Maret 2015).

${ }^{30}$ Achmad Ali, Menguak Teori Hukum Dan Teori Peradilan (Jakarta: Kencana Prenada Media Group, 2009 ), 375.

${ }^{31}$ Achmad Ali, Menguak Teori Hukum Dan Teori Peradilan, 378.
}

Jurisdictie: Jurnal Hukum dan Syariah Vol. 6 No. 2 Desember 2015 
Kondisi kedewasaan individu pada saat ini cenderung mengalami kemunduran. ${ }^{32}$ Sebagaimana paparan yang ada sebelumnya, bahwa telah diambil konklusi batasan usia dengan berbagai petimbangan, yaitu 21 tahun bagi laki-laki dan 18 tahun bagi perempuan. Dengan kondisi yang demikian ini, berdasarkan prinsip pasif-dinamis hendaknya batasan minimal usia kawin yang ada pada Undang-Undang Perkawinan dinaikkan menjadi 21 bagi laki-laki dan 18 bagi perempuan. Karena kondisi kedewasaan remaja saat ini yang cenderung melambat.

\section{Kesimpulan}

Berdasarkan pembahasan di atas, dapat ditarik kesimpulan bahwa Hakim Pengadilan Agama Kabupaten Malang menyatakan bahwa batasan usia yang ada pada UU Perkawinan kurang sesuai untuk diterapkan saat ini. Mereka lebih sepakat kalau batasan usia tersebut dinaikkan. Agar usulan ini dapat terlaksana dengan baik, perlu dibarengi dengan adanya penambahan pasal-pasal pada sub dispensasi kawin yang menjelaskan mengenai syarat-syarat permohonan dispensasi kawin. Hal ini dimaksudkan agar hakim lebih mudah dalam memeriksa dan memutus perkara dispensasi kawin ini. Perlu diusulkan juga agar syarat-syarat pengajuan dispensasi kawin ini diperketat, supaya kasus dispensasi kawin ini dapat diminimalisir. Sejalan dengan itu, untuk membentuk masyarakat yang pro-aktif terhadap ketentuan batasan usia kawin ini perlu dilakukas sosialisasi secara intens, terutama di daerah-daerah plosok desa. Hal ini menjadi tanggung jawab bersama Pengadilan Agama, Kantor Urusan Agama, dan Perangkat Desa. Dengan demikian akan tercipta masyarakat yang sehat, sejahtera, bahagia, dan aman dari perceraian.

Dosen Psikologi UIN Malang memandang bahwa batas minimal usia kawin yang diatur dalam UU Perkawinan No. 1 Tahun 1974 dianggap kurang patut untuk saat ini, karena UU ini dibuat pada tahun 1974. Sedangkan dari tahun ke tahun konsep perkembangan dan kedewasaan manusia selalu mengalami perubahan. Dengan melakukan sintesis terhadap pendapat Dosen Psikologi tersebut dan juga berdasar pada teori tentang psikologi perkembangan dapat dirumuskan bahwa batasan usia minimal kawin yang ada pada UU Perkawinan harusnya dinaikkan. UU Perkawinan saat ini kurang relevan untuk diterapkan pada masyarakat. Terutama penerapan pasal mengenai batasan minimal usia kawin. Hal ini berdasarkan fakta bahwa unsur substansi hukum dan budaya hukum yang menjadi faktor penting dalam penegakan hukum belum tercukupi secara maksimal. Apabila faktor-faktor dari penegakan hukum tersebut tidak tercukupi secara optimal, maka patut untuk dipertanyakan keefektifannya. Berdasarkan analisis yang telah peneliti lakukan, dengan mengkorelasikan antara teori, pendapat hakim, dan dosen psikologi dapat ditarik sebuah konklusi bahwa batas minimal usia kawin yang sesuai untuk saat ini adalah 21 tahun bagi laki-laki dan 18 tahun bagi perempuan. Hal ini bertujuan untuk menciptakan keluarga yang harmonis serta menekan jumlah perceraian.

\section{Daftar Pustaka}

Achmad Ali. Menguak Teori Hukum Dan Teori Peradilan. Jakarta: Kencana Prenada Media Group, 2009.

Agustiani, Hendriati. Psikologi Perkembangan: Pendekatan Ekologi Kaitannya Dengan Konsep Diri Dan Penyesuaian Diri Pada Remaja. Bandung: Refika Aditama, 2006.

Alwisol. Psikologi Kepribadian. Malang: UMM Press, 2007.

Arikunto, Suharsimi. Prosedur Penelitian: Suatu Pendekatan Praktek. Jakarta: Rineka Cipta, 2006.

\footnotetext{
${ }^{32}$ Lubab, Wawancara, (Fakultas Psikologi UIN Malang, 12 Maret 2015).

Jurisdictie: Jurnal Hukum dan Syariah Vol. 6 No. 2 Desember 2015
} 
Az-Zuhaili, Wahbah. Al-Fiqh Al-Islam Wa Adillatuhu. Beirut: Dar al-Fikr, 2008.

Hanafi, Yusuf. Kontroversi Perkawinan Anak Di Bawah Umur Perspektif Fikih Islam, HAM Internasional, Dan UU Nasional. Bandung: Mandar Maju, 2011.

HS, Salim, and Erlies Septiana Nurbani. Penerapan Teori Hukum Pada Penelitian Tesis Dan Disertasi. Jakarta: PT RajaGrafindo Persada, 2013.

Latif, Sutan Marajo Nasaruddin. Problematika Seputar Keluarga Dan Rumah Tangga. Bandung: Pustaka Hidayah, 2001.

Ramadhita. "Diskresi Hakim: Pola Penyelesaian Kasus Dispensasi Perkawinan." De Jure: Jurnal Hukum Dan Syar'iah 6, no. 1 (June 30, 2014). doi:10.18860/j-fsh.v6i1.3192.

Soemanto, Wasty. Psikologi Pendidikan Landasan Kerja Pemimpin Pendidikan. Jakarta: Rineka Cipta, 1984.

Suma, Muhammad Amin. Himpunan Undang-Undang Perdata Islam \& Peraturan Pelaksanaan Lainnya di Negara Hukum Indonesia. Jakarta: RajaGrafindo Persada, 2004.

Syarifuddin, Amir. Hukum Perkawinan Islam di Indonesia: Antara Fiqh Munakahat dan Undang-Undang Perkawinan. Jakarta: Kencana, 2008.

Zulkifli. Psikologi Perkembangan. Bandung: PT Remaja Rosdakarya, 2005. 